\title{
The Determinants of the Rate of Housing Deterioration in High Density and Slum Areas of Nigerian Cities with Particular Reference to Enugu City
}

\author{
Dr. B. O. Uwadiegwu Mnitp, Rtp \\ Department Of Environmental Management Nnamdi Azikiwe University, Awka, Anambra State
}

\begin{abstract}
The aim of the study is to identify causal factors which determine the rate of housing deterioration particularly in high density and slum areas of Nigerian cities. Two high density areas, namely, Asata and Ogui New Layout and one slum area, Obiagu, all in Enugu City were used for the study. 257 landlords randomly selected from these areas participated in this study by serving as respondents. Structured questionnaire was the major instrument for data collection. Multiple Linear, Regression Analysis (MRA) was used in data analysis. Findings indicate that out of the 7 suspected factors, 5 of them, namely, high occupancy ratio (0.968), number of non-residential rooms (0.875), Landlord's level of education (0.675), Landlord's household size (0.593) and number of tenants (0.406) correlate significantly with housing deterioration. Therefore, the more these identified factors are combined in a dwelling unit, the faster the rate of deterioration of that dwelling. It is then recommended that governments at all levels should give adequate enabling environment to municipal councils through Town Planning Authorities to enforce acceptable occupancy ratios and codes. Similarly, the issue of family planning should be pursued with more vigor and determination to the extent that offenders could be sanctioned and prosecuted. Further more, landlords' education should be made mandatory and to be extended to include information communication technology (ICT) to enable them link up with the outside world for greater awareness and networking. The study then concluded that though the study was based in Enugu city but the findings are germane to other Nigerian as well as third world cities.
\end{abstract}

Keywords: Deterioration, housing, household, landlord, tenants and occupancy.

\section{Introduction}

A community, be it rural or urban, is an ecological unit, it grows and in the process, parts become aged (due to age, misuse or lack of care) and without regenerative actions, such parts decay and fall into dis-use (Onibokun, 1985). Housing decay manifests in various forms and exists in almost all the parts of a city but perhaps more evident in the slum and other high density areas of the city.

Some indicators of housing decay include rustic roof, open ridges and up lifted overlaps, indented ends, lost or hanging facia, twisted and loose doors and windows, cracked walls, exposed foundation, peeled off paints and dangerously handing walls. These indicators do not just appear but owe their existence to several causal factors which may include age and neglect as obvious ones.

Much concern have been shown about the problems of the slum areas particularly on the level of decay exhibited by such areas and the plight of the low income households which dwell in them. Many academicians and professionals have drawn attention to the multi-dimensionality of the problems facing slum and high density areas in Nigerian cities. Some of them include; Bascom, 1975, Lloyd, 1960, Mitchel, 1962, Miner, 1960, Mabogunye, 1985, Egunjobi, 1985, Agbola, 1985 and Omole, 2000). Most of their concern concentrate on the deplorable conditions of the slum areas, the plight of the dwellers, inadequate facilities and amenities, room densities, lack of sewers and waste disposal facilities. They have also suggested good measures to be adopted in addressing the slum problems adequately. The objective of this study is not to criticize their focuses but to provide a new strategy for addressing the housing problems of the slum areas. This strategy is based on the assumption that if the causes of housing decay and deterioration are identified holistically, then it becomes possible to adduce adequate management measures aimed at eradicating such factors which cause housing deterioration. It is believed that elimination of such factors will lead to the emergence of tolerable housing situation in the slum areas, improve the dwindling housing stock and inject a new lease of life among the dwellers as well as save the huge expenses usually involved in outright comprehensive urban renewal programmes. Therefore the main aim of this study is to identify the controllable causal factors which determine the rate of housing deterioration in high density neighbourhoods and particularly in the slum areas. The management of such factors will complement other in-situ urban renewal measures such as rehabilitation and conservation approaches. 
Two high density neighbourhoods, namely, Asata and Ogui New Layout and one slum area, Obiagu all in Enugu City, were used for this study.

\section{Conceptual Framework}

This study is based on the concept of urban problem dynamism. This concept postulates that the problems of urban dynamism can be classified into physical, social, economic, textural and management sub groups. The physical aspect of the urban environment usually manifests landuse and blight problems. Incongruous landuse development and lopsidedness are common place landuse problems. On the other hand, blight problems assume the form of physical deterioration which occurs due to age, poor usage performance, relative lack of maintenance and large environmental conditions. Most times, it is collaborated in the definition of city decay even though city decay may mean more than that. The social sphere problem is informed by urban population explosion towards urban living. This is not unrelated to low quality of population characteristics as measured by high illiteracy and anonymousity that mark the urban society. Hence poverty, large family size, high occupancy ratio and low income are common place social problems in the urban milieu. On the other hand, urban economics is marked by low productivity with its attendant problems. These problems are indicated by unemployment and underemployment. Most of the redundant labour force finds solace in informal sector activities, which has lots of adverse environmental implications. Overall, a defective urban economic base is central to all urban problems. The urban texture is related to urban form but is more concerned with the densities of development and occupancy ratios. A poor combination of the residential accommodation and population densities plus high occupancy ratio may result to overcrowding problems and claustrophobia that result to tension and stress in the performance of urban systems. This condition accelerates urban decay.

Urban problems can be absolute or relative, reversible or irreversible. They are mutually related and their rate of manifestation varies depending on causal factors. At any point in time, these problems in their various subsets are at different stages of occurrence. Overall, their effect retard urban productivity, city attractiveness and environmental health indicators. The degree of retardation as defined by various societies determine slum situation. In most cases, slum conditions are identified when the problems are absolute and irreversible (Okeke, 2002).

\section{Methodology}

The study adopted survey design in that the major instrument used for data collection is the pre-coded questionnaire. A total of 260 copies of questionnaire were distributed to the 3 layouts used for the study. Return record of the questionnaire is as follows; Asata (87), Ogui New Layout (85) and Obiagu (85), meaning that 257 copies of the questionnaire were used for this copy. These questionnaires were administered to landlords and landladies or their caretakers who were randomly selected from the three layouts.

In order to provide guidance and direct the pattern and progress of the study, the study was formulated in the form of hypothesis which reads:

Ho: There is no significant relationship between housing deterioration $(\mathrm{Y})$ and occupancy ratio $\left(\mathrm{X}_{1}\right)$, Landlord's level of education $\left(\mathrm{X}_{2}\right)$, Landlord's income $\left(\mathrm{X}_{3}\right)$, his household size $\left(\mathrm{X}_{4}\right)$, number of tenants $\left(\mathrm{X}_{5}\right)$, number of non-residential rooms $\left(\mathrm{X}_{6}\right)$ and amenities available $\left(\mathrm{X}_{7}\right)$.

The appraisal method adopted for the measurement of housing quality or level of deterioration (Y) is that developed by the American Public Health Association (APHA) in 1964. The scores consist of penalty points assigned to conditions that fail to meet a reasonable contemporary housing standard. Penalties rather than credit scores are used because the method measures departures downwards from a base of acceptability. (George, 1999). $X_{1}$ to $X_{7}$ were measured by the absolute numbers existing for each of the variables in each residential house.

Multiple Linear Regression Analysis (MRA) was used in analyzing the raw data collected. The correlation matrix of the analysis is shown in Table 1.

Table 1: Multiple Correlation Analysis (MCA)

\begin{tabular}{|l|c|r|r|r|r|r|r|r|}
\hline & $\begin{array}{c}\text { Rate of } \\
\text { Building } \\
\text { code } \\
\text { Contraven } \\
\text { tion }\end{array}$ & $\begin{array}{c}\text { Occupan } \\
\text { cy } \\
\text { Ratio }\end{array}$ & $\begin{array}{c}\text { No of } \\
\text { non- } \\
\text { residenti } \\
\text { al rooms }\end{array}$ & $\begin{array}{c}\text { Level of } \\
\text { Educati } \\
\text { on }\end{array}$ & $\begin{array}{c}\text { No of } \\
\text { House } \\
\text { hold }\end{array}$ & $\begin{array}{c}\text { Income } \\
\text { per } \\
\text { annum }\end{array}$ & $\begin{array}{c}\text { Avera } \\
\text { ge no } \\
\text { of } \\
\text { Tenan } \\
\text { ts }\end{array}$ & $\begin{array}{c}\text { Ameniti } \\
\text { es } \\
\text { Availab } \\
\text { le }\end{array}$ \\
\hline $\begin{array}{l}\text { Rate of } \\
\text { Building code } \\
\text { Contravention }\end{array}$ & 1 & -002 & -010 & -026 & .033 & $-204 * *$ & .052 & $-223^{* *}$ \\
& 258 & .968 & .875 & .675 & .593 & .001 & .406 & .000 \\
& 258 & 258 & 258 & 258 & 258 & 258 & 257 \\
\hline
\end{tabular}


The Determinants Of The Rate Of Housing Deterioration In High Density And Slum Areas Of

\begin{tabular}{|c|c|c|c|c|c|c|c|c|}
\hline $\begin{array}{l}\text { Occupancy } \\
\text { Ration }\end{array}$ & $\begin{array}{r}-002 \\
968 \\
258\end{array}$ & $\begin{array}{r}1 \\
259\end{array}$ & $\begin{array}{l}-006 \\
.927 \\
259\end{array}$ & $\begin{array}{l}.028 \\
.655 \\
259\end{array}$ & $\begin{array}{l}.056 \\
.373 \\
259\end{array}$ & $\begin{array}{l}.101 \\
.105 \\
258\end{array}$ & $\begin{array}{r}.272 * * \\
.000 \\
259\end{array}$ & $\begin{array}{r}-169 * * \\
.006 \\
258\end{array}$ \\
\hline $\begin{array}{l}\text { No of non- } \\
\text { residential } \\
\text { Rooms }\end{array}$ & $\begin{array}{r}-010 \\
875 \\
258 \\
\end{array}$ & $\begin{array}{l}-006 \\
.927 \\
259 \\
\end{array}$ & $\begin{array}{r}1 \\
259 \\
\end{array}$ & $\begin{array}{r}-081 \\
.196 \\
259 \\
\end{array}$ & $\begin{array}{r}.146^{*} \\
.019 \\
259\end{array}$ & $\begin{array}{r}-117 \\
.060 \\
259 \\
\end{array}$ & $\begin{array}{r}-040 \\
.526 \\
259\end{array}$ & $\begin{array}{l}.122 \\
.050 \\
258\end{array}$ \\
\hline $\begin{array}{l}\text { Level of } \\
\text { Education }\end{array}$ & $\begin{array}{r}-026 \\
675 \\
258\end{array}$ & $\begin{array}{l}.028 \\
.655 \\
259\end{array}$ & $\begin{array}{l}-081 \\
.196 \\
259\end{array}$ & $\begin{array}{r}1 \\
259\end{array}$ & $\begin{array}{r}-022 \\
.726 \\
259\end{array}$ & $\begin{array}{r}.197 * * \\
.001 \\
259\end{array}$ & $\begin{array}{l}.008 \\
.897 \\
259\end{array}$ & $\begin{array}{r}.132 * \\
.035 \\
258\end{array}$ \\
\hline $\begin{array}{ll}\text { No } & \text { of } \\
\text { household }\end{array}$ & $\begin{array}{l}.033 \\
.593 \\
258\end{array}$ & $\begin{array}{r}.056 \\
.373 \\
2259\end{array}$ & $\begin{array}{r}-081 \\
.019 \\
259\end{array}$ & $\begin{array}{r}-022 \\
.726 \\
259\end{array}$ & $\begin{array}{r}1 \\
259\end{array}$ & $\begin{array}{r}-070 \\
.260 \\
259\end{array}$ & $\begin{array}{l}.097 \\
.127 \\
259\end{array}$ & $\begin{array}{l}.078 \\
.214 \\
258\end{array}$ \\
\hline $\begin{array}{ll}\begin{array}{l}\text { Income } \\
\text { annum }\end{array} & \text { per }\end{array}$ & $\begin{array}{l}-204 \\
.001 \\
258\end{array}$ & $\begin{array}{l}.101 \\
.105 \\
259\end{array}$ & $\begin{array}{r}-117 \\
.060 \\
259\end{array}$ & $\begin{array}{r}.197 * * \\
.001 \\
259\end{array}$ & $\begin{array}{r}-070 \\
.260 \\
259\end{array}$ & $\begin{array}{r}1 \\
259\end{array}$ & $\begin{array}{l}.095 \\
.127 \\
259\end{array}$ & $\begin{array}{r}.275^{* *} \\
.000 \\
.189\end{array}$ \\
\hline $\begin{array}{l}\text { Average no of } \\
\text { tenants }\end{array}$ & $\begin{array}{l}.052 \\
.406 \\
258\end{array}$ & $\begin{array}{l}.272 \\
.000 \\
259\end{array}$ & $\begin{array}{r}-040 \\
.526 \\
259\end{array}$ & $\begin{array}{l}.008 \\
.897 \\
259\end{array}$ & $\begin{array}{l}.095 \\
.127 \\
259\end{array}$ & $\begin{array}{r}-059 \\
.343 \\
259\end{array}$ & $\begin{array}{r}1 \\
259\end{array}$ & $\begin{array}{r}-082 \\
.189 \\
258\end{array}$ \\
\hline $\begin{array}{l}\text { Amenities } \\
\text { available }\end{array}$ & $\begin{array}{r}-223 \\
.000 \\
257\end{array}$ & $\begin{array}{r}-169 \\
.006 \\
258\end{array}$ & $\begin{array}{l}.122 \\
.050 \\
258\end{array}$ & $\begin{array}{r}.132 * \\
.035 \\
258\end{array}$ & $\begin{array}{l}.078 \\
.214 \\
258\end{array}$ & $\begin{array}{r}.275^{* *} * \\
.000 \\
258\end{array}$ & $\begin{array}{r}-082 \\
.189 \\
258\end{array}$ & $\begin{array}{r}1 \\
258\end{array}$ \\
\hline
\end{tabular}

$* *$ Correlation is significant at the 0.01 level (2-tailed)

* Correlation is significant at the 0.05 level (2-tailed).

When the variables $X_{1}$ to $X_{7}$ were independently correlated one against $y$, and their standard deviations from their group mean determined, at 0.05 significant level, five variables out of the seven variables were identified to correlate significantly with $\mathrm{Y}$. The variables are (1) occupancy ratio, $\mathrm{X}_{1}(0.968)$, number of non-residential rooms, $\mathrm{X}_{6}(0.875)$, landlords level of education, $\mathrm{X}_{7}(0.675)$, household size, $\mathrm{X}_{4}(0.593)$, and weakly with overage number of tenants, $\mathrm{X}_{3}(0.406)$ Occupancy ratio and number of non-residential rooms with high correction indices are variables which influence rate of housing deterioration. (Tables 2, 3, 4 and 5).

Table 2: Standard Deviation of Correlation

\begin{tabular}{|l|r|r|c|}
\hline & \multicolumn{1}{|c|}{ Mean } & Std. Deviation & N \\
\hline Rate of building code contravention & 6.51 & 2.153 & 257 \\
\hline Occupancy ratio & 3.13 & 1.194 & 257 \\
\hline No of non-residential rooms & 1.16 & 1.780 & 257 \\
\hline Level of education & 11.96 & 13.769 & 257 \\
\hline No of household & 5.472 & 9.6877 & 257 \\
\hline Income per annum & 235.64 & 286.262 & 257 \\
\hline Average no of tenants & 6.677 & 8.9601 & 257 \\
\hline Amenities available & 3.61 & 1.295 & 257 \\
\hline
\end{tabular}

Table 3 (Summary of Multiple Correlation Analysis)

\begin{tabular}{|c|c|c|c|c|c|c|c|c|c|}
\hline \multirow[b]{2}{*}{ Model } & \multirow[b]{2}{*}{$\mathbf{R}$} & \multirow{2}{*}{$\begin{array}{c}\text { R } \\
\text { square }\end{array}$} & \multirow{2}{*}{$\begin{array}{l}\text { Adjusted } \\
\text { R square }\end{array}$} & \multirow{2}{*}{$\begin{array}{c}\text { Std. } \\
\text { Error of } \\
\text { the } \\
\text { Estimate } \\
\end{array}$} & \multicolumn{5}{|c|}{ Change Statistics } \\
\hline & & & & & $\begin{array}{c}\text { R } \\
\text { square } \\
\text { Change }\end{array}$ & $\begin{array}{c}\mathbf{F} \\
\text { change }\end{array}$ & df1 & df2 & $\begin{array}{l}\text { Sig. F } \\
\text { change }\end{array}$ \\
\hline 1 & $.277^{\mathrm{a}}$ & .077 & .051 & 2.097 & .077 & 2.955 & 7 & 249 & \\
\hline
\end{tabular}

a. Predictors: (Constant), Amenities available, No of household, Average no of tenants, level of education, No of non-residential rooms, occupancy Ratio, income per annum

b. Dependent variable: Rate of Building Deterioration. 
Analysis of variance (ANOVA) was performed to identify the co-efficient of determination of the seven variables. Five variables showed co-efficient that are significant at 0.05 level of significance. These are occupancy ratio $\left(\mathrm{X}_{1}\right)$, number of non-residential rooms $\left(\mathrm{X}_{6}\right)$, Landlords' level of education $\left(\mathrm{X}_{7}\right)$, household size $\left(\mathrm{X}_{4}\right)$, and average number of tenants $\left(\mathrm{X}_{3}\right)$.

Table 4: ANOVA $^{\mathrm{b}}$

\begin{tabular}{|l|l|r|r|r|r|r|}
\hline & \multicolumn{1}{|c|}{ Model } & $\begin{array}{c}\text { Sum of } \\
\text { squares }\end{array}$ & Df & Mean square & \multicolumn{1}{c|}{ F } & Sig. \\
\hline 1 & Regression & 90.983 & 7 & 12.998 & 2.955 & $.005^{\mathrm{a}}$ \\
& Residual & 1095.258 & 249 & 4.399 & & \\
& Total & 1186.241 & 256 & & & \\
\hline
\end{tabular}

c. Predictors: (Constant), Household size, Average no of tenants, level of education, No of non-residential rooms and occupancy Ratio.

d. Dependent variable: Rate of Building Deterioration

Table 5: Coefficients

\begin{tabular}{|c|c|c|c|c|c|c|}
\hline & \multirow[b]{2}{*}{ Model } & \multicolumn{2}{|c|}{$\begin{array}{l}\text { Unstandardize } \\
\text { Coefficients }\end{array}$} & \multirow{2}{*}{$\begin{array}{c}\text { Standardized } \\
\text { Coefficients } \\
\text { Beta }\end{array}$} & \multirow[b]{2}{*}{$\mathbf{t}$} & \multirow[b]{2}{*}{ Sig. } \\
\hline & & 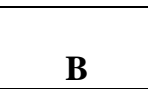 & $\begin{array}{c}\text { Std. } \\
\text { Error }\end{array}$ & & & \\
\hline \multirow[t]{8}{*}{1} & (Constant) & 7.782 & .679 & & 11.460 & .000 \\
\hline & Occupancy ratio & -.053 & .118 & -.030 & -.454 & 0.968 \\
\hline & No of non-residential rooms & -.007 & .076 & -.006 & -.098 & 0.875 \\
\hline & Level of education & .018 & .036 & .031 & -2.499 & 0.675 \\
\hline & No of household & .008 & .014 & .038 & -1.606 & 0.592 \\
\hline & Income per annum & -.001 & .000 & -.155 & -2.340 & 0.05 \\
\hline & Average no of tenants & .008 & .015 & .031 & -2.493 & 0.406 \\
\hline & Amenities available & -.315 & .110 & -.189 & .855 & 0.03 \\
\hline
\end{tabular}

\section{Findings And Discussion}

The result of the hypothesis testing shows that the rate of housing deterioration relates highly with high occupancy ratio, number of non-residential rooms, landlords' level of education, household size and average number of tenants.

High occupancy ratio result to occupancy stress and over utilization of space and amenities which bring about outright tear and wear of residences. High occupancy ratio is a direct consequence of low capital formation of the less privileged households. Their income is only enough for their sustenance. This makes them to choose living up to 4-6 in a room so as to collectively afford the rent. Poor households cannot afford more than two rooms no matter the size of their households which is usually large in Nigeria.

The number of non-residential rooms in a housing unit is also a factor of housing deterioration. This is because as more rooms in a house are being devoted to retail shops, drinking parlours, stores, restaurants etc over utilization is as well encouraged which can lead to high rate of tear and wear and hence intensification of deterioration.

The level of landlord's education is a very crucial factor in determining the rate of housing deterioration. This is so because a highly educated landlord will understand the need for decency and thus aspires to maintain a high level of occupancy codes and hence maintain his residence to protect his obode from falling into a state of disrepair. Less educated landlords are less conscious of occupancy codes and decency and tend to neglect the maintenance of their residences which soon degenerate into several defects.

The numerical size of the landlord's household has been identified as one of the factors that facilitate housing deterioration. This is so because the higher the size of households, the greater the number of dependents with the result that such landlords will expend greater proportion of their income in household upkeep, maintenance and management with little or none left for housing maintenance and protection. The major concern of such landlord is how to ensure adequate and regular sustenance for his family, pay tuition, hospital bills etc with little or no concern for the declining value of his house and hence creates conditions for deterioration of his house. One of the ugly consequences of the unabated influx of people into the cities from the surrounding rural areas is the increase of number of persons per dwelling particularly in high density and slum areas of the city. It is not uncommon to find cases of more than 30 persons to a dwelling as against permissible 10 persons per dwelling (Acquaye, 1985) in Nigeria cities. This scenario manifests in many tenants 
per dwelling unit which has similar deteriorating effect as high occupancy ratio. So many tenants per dwelling unit add enormous pressure on such dwelling and as such hasten its depreciation rate.

It is worthy to point out that these identified causal factors interact and reinforce each other in such a way that in a situation where more than one of such factors operate, the rate of housing deterioration is very high, and in a house where all the factors exist at the same time, such a house shatters within a couple of years because its useful life span is quite limited.

\section{Recommendations}

For the purpose of prolonging the useful service life of dwelling units in the high density and slum areas and to ensure they are kept and maintained at a high standard of living, a number of measures need to be taken which include but not limit to;

(1) Government should give municipal councils through their town planning authorities adequate powers and support to carry out their statutory responsibilities which include enforcement of occupancy ratios and codes. This kind of enforcement will reduce the adverse effects of high room densities. However, this will only be practicable if government doubles its efforts in provision of adequate housing at rates affordable to these low income households. There most be regulations prohibiting landlords from exceeding stipulated number of tenants per dwelling.

(2) Similarly, the issue of family planning should be disseminated with more vigor and determination with the purpose of educating the masses on the ugly consequences of large family size. The programme should not be propagated as an issue of philosophical ethics to which couples can adopt by choice but as a serious societal social objective to which compliance is not only mandatory but enforceable in the court of law for sanctions.

(3) Landlords' education should not be limited to ability to read and write but to reorientate their mentalities to reposition themselves on the current emphasis of utilization of information communication technology (ICT). They must be educated to the extent that they will be linked internationally to avail themselves of the increasing opportunities of globalization and hence learn what is acceptable and be prepared to adopt what is acceptable. In order to achieve this, government must establish and encourage adult schooling system with emphasis on information communication technology (ICT) which must be reasonably subsidized.

\section{Conclusion}

The factors responsible for the rate of housing depreciation and deterioration are exacerbated when other factors such as high occupancy ratio; number of rooms devoted to non-residential uses, limited landlord's education, large household size and two many tenants are added. Though the findings of this study are based on the study of high density and slum areas in Enugu, but this true for similar areas in other cities in Nigeria as well as in other third world countries. Rather than expending large expenses on outright urban renewal programmes and control, prudent management of the identified factors may go a long way to eliminating the incidence of housing deterioration and hence arrest the formation and existence of true slum in Nigerian cities.

All levels of government have a duty to perform in order to save Nigerian cities from physical obsolescence and blight. This will improve the aesthetic and livability levels of Nigerian cities.

\section{References}

[1] Acquaye, E. (1985), A Teleological Review of The Housing Problem in Developing Countries, Housing in Nigeria, A Book of Readings, Onibokun, P. (ed.), Nigerian Institute of Social and Economic Research (NISER), Ibadan, (Pub.).

[2] Agbola, T. (1985), "Property Taxation", Paper Presented at a Seminar on Local Sources of Finance for Local Government, ASCON, Lagos.

[3] Bascom, W. (1975), Urbanization Among the Yorubas, American Journal of Sociology, Vol. IX, No. 5, pp. 446-454

[4] Egunjobi, L. (1985) "Urban Renewal: Issue, Politics, Strategies and Planning”, Urban Renewal in Nigeria, Onibokun et al (eds), pp. 33-42.

[5] Miner, H. (1960) “Cultural Change Under Pressure”, Human Organization, Vol. XIX, No. 3, pp. 164-167.

[6] Mitchel, N. C. (1962) Yoruba Towns, Essays on African Population, K. M. Barbour and R. M. Prothero (eds), New York, Praeger.

[7] Mabogunye, A. L. (1985), "Towards An Urban Policy in Nigeria", Housing in Nigeria (A Book of Readings), Onibokun, P. (ed), NISER Publications.

[8] Omele, F. K. (2000), Urban Renewal Process, Issues and Strategies, Concept Books and Publication Company, Nigeria Ltd. Ikeja, Lagos.

[9] Onibokun, P. (1985), "Nigerian Cities: Their Rehabilitation and Redevelopment", Housing in Nigeria (A Book of Readings), Onibokun, P. (ed.), NISER (Pub.), Ibadan, Nigeria.

[10] Okeke, D. C. (2002), Environmental and Urban Renewal Strategies, (Theoretical and Analytical Framework), Institute for Development Studies (Pub.), Enugu, Nigeria. 